\title{
Article
}

\section{Seeing Red:}

\author{
Violence and Cultural Memory in D'Arcy McNickle's \\ The Surrounded
}

Paul Whitehouse

THE NATIVE AMERICAN IN LITERATURE stands as a figure 'surrounded', at times overwhelmed, by a complex and violent history, constantly attempting to communicate with, preserve, and remember an increasingly endangered way of life. The historian Frederick E. Hoxie, captured the essence of this ongoing process when he described the Native American position, in both political and cultural terms, as 'the search for a new home in a captured land'. With this thought in mind, this article examines the relationship between violence, cultural memory and Native identity in D'Arcy McNickle's The Surrounded (1936), a seminal twentieth-century Native American novel. In exploring these issues, I use Slavoj Žižek's theory of systemic violence as a means of positioning the central protagonist's feeling of disjuncture between his inherited cultural past and his experience of violence in the present. I argue that, through a series of self-affirming violent episodes, the protagonist is able to reconnect to a symbolic, pre-colonial past and, in that instant, both recognise and challenge the institutionalized, legislative, and normative violence that has stifled his individual development and threatens to engulf the cultural identity of his 
wider Native community. The first section of the article offers brief introductions to Žižek's theory of systemic violence and the author D'Arcy McNickle, before discussing the role of cultural memory in the novel. The second section of the essay analyses the function of systemic violence, arguing that violent episodes in the narrative represent attempts to break free from the invisible bonds of systemic violence in pursuit of a new, hybridic Native identity.

\section{Žižek and systemic violence}

Žižek defines systemic violence as the often 'catastrophic consequences of the smooth functioning of our economic and political systems.' ${ }^{2}$ In other words, the unfortunate and destructive fallout of a well-functioning society. He suggests that objective violence is the violence 'inherent to this "normal" state of things', a form of invisible violence which 'sustains the zero-level standard against which we perceive something as subjectively violent'. What emerges is a model of a supposedly smooth-running society in which systemic violence operates unseen to the subjective bystander, only occasionally manifesting itself in overt episodes of 'irrational' violence, so called because they represent a bizarre, unconventional, and often shocking break with what would normally be expected. Within such a society these overt acts of episodic 'irrational' violence are dismissed as the inexplicable but necessary side-effects of a 'normal' society, rather than a symptom of an underlying systemic violence or failure. For all parties involved the true cause of the irrational act is either unknown or obscured by an ideological bias. Žižek explains that systemic violence can become so engrained as to become ostensibly invisible to everyone involved, in effect part of a cultural unconsciousness, and this is where his model becomes crucial to understanding the role of violence in Native American literature. The invisible nature of systemic violence makes it especially difficult to place blame or assign responsibility for acts of such violence, since each act is part of a much larger and more complex system and perception has been framed and informed by the same systems that disadvantage specific ideas, groups, or entire populations.

In McNickle's novel the entire Native population of the Flathead Indian reservation in Montana in the early 1930s is subject to the forces of an imposed colonial and ideological order. Episodes of violence are aimed at symbols of authority and ideological constraint, such as the warden and local sheriff, who maintain law and order on the reservation and the Catholic missionary school. Acts of violence directed towards these symbols of authority are in turn deemed irrational by outside observers since they are seen as an attack on those organs of power meant to protect and nurture the Native community. In this context killing the warden and, later, the sheriff does not serve any reasonable purpose, and only results in making life more difficult for those involved. Similarly, the Jesuits who run the missionary school and minister to the Native community are appalled when the protagonist's mother rejects her Catholic faith on her deathbed. The priest sees her rejection as an attack not only on the institution of his church, but also as an irrational break from the spiritual life which the 
mission has spent generations trying to establish within the community. Žižek's model interprets 'irrational' events like these as a reaction against the unseen systemic violence signified in this instance by the warden, sheriff, and Jesuit priest. Accordingly, we can say that such events are only 'irrational' when viewed as a superficial attack on the symbolic order. Žižek tells us that against the normative background of everyday society such outbursts look ridiculous and misguided, but become rational when interpreted as a direct, although often unconscious, attack on what lies beneath the surface, in this case a form of underlying colonial violence which seeks to erode and translate what remains of a traditional Native American cultural identity on the reservation.

In terms of Native American literature it is helpful to conceive of systemic violence as a form of legislative violence, since Native Americans have witnessed firsthand the degrading effects of the colonial agenda, from the denial of legal rights and the breaking of treaty law, theft of ancestral lands, and attacks on their cultural legitimacy. In The Surrounded, systemic violence manifests itself in the practice of state and federal legislation in the guise of Indian land reform and the policing of all aspects of life on the reservation. By applying Žižek's model it is possible to unpick the complex relationship between the cause and event of violence in the narrative. For some characters this process begins to reveal the inherent violence that underpins their existence on the reservation, which in turn gives rise to the formation of a new, hybridic identity.

\section{D'Arcy McNickle's The Surrounded and Native American Politics}

Out of print for much of its history and only reissued in 1977, The Surrounded is now recognised as a major novel within the Native American literary tradition, and one of the founding texts of the new Indian writing, which, by the 1980s, had done for the Native American canon what the Harlem Renaissance had done for black literature. ${ }^{3}$ It was written over the course of nine years during a period of immense political and social change in the United States, and presents a complex psychological portrait of reservation life in New Deal America, emphasising the demoralising effect that the allotment process imposed upon Native American communities. ${ }^{4}$ More importantly, McNickle's novel became a beacon for subsequent Native American writers in that it significantly expands and develops themes and literary motifs established in embryo in its immediate predecessor, John Joseph Mathews's Sundown (1934). ${ }^{5}$

In plotting the developmental genesis of cultural memory and violence in Native American literature, The Surrounded stands as a logical starting point in that it inspired the next generation of Native American and Mixed Blood writers to engage in a critical dialogue with the themes presented in the novel; it is considered to be the most complex treatment of the Mixed Blood community identity before the publication of M. Scott Momaday's House Made of Dawn (1987). A. Lavonne Brown Ruoff, Robert Warrior, and Louis Owens have written extensively on the importance of McNickle's novel as a keystone text within the Mixed Blood literary tradition, with Archilde, the deeply 
troubled central character, continuing to stand as the prototype for the protagonists of novels written by Native American authors. ${ }^{6}$

The cross-cultural conflict, presented in the character of Archilde, a young man torn between life on the reservation and life beyond its boundaries, is a theme which McNickle revisits in his later novels, although never again with such poignant immediacy. His major anthropological work, Native American Tribalism: Indian Survivals and Renewals (1973), would help to redefine the new academic focus of the emergent Indian movements of the 1970s and 1980s. In it McNickle presents a historical overview of the Native American experience written from their own perspective, a move that even in 1973 was something of a first amongst Native American historians. It is a fiercely passionate work with an underlying militancy intended to remind those who believed that Native Americans were a disappearing and endangered race that Indians were here to stay. But it is in The Surrounded that we find McNickle's most affecting expression of the conditions facing Native American and Mixed Blood Indians during a time when important changes emerged in Federal Indian Policy under the direction of Commissioner of Indian Affairs John Collier, with whom McNickle became a close ally, and whose passionate beliefs in the enduring regeneration of Native communities he shared.

It is clear that many of McNickle's ideas regarding new directions in Indian identity politics presented in Native American Tribalism, had been formed already by the time he wrote The Surrounded, particularly the conflicted relationship between those who believed in a return to a more traditional cultural existence and those who sought to assert an alternative, hybridic position, invoking the spirit of the past in the form of collective tribalism and a united Native community. ${ }^{7}$ In this regard, Archilde stands as a collective metaphor for Native people across America; people standing at a juncture between the final, violent act of colonial assimilation and possible annihilation, and a relentless and exhausting reservation existence.

In a sentiment reminiscent of Frantz Fanon, Mixed Blood author Howard Adams argues that, historically speaking, colonised Native people are 'not allowed a valid interpretation of their history, because the conquered do not write their own history', and that it is their lot to 'endure a history that shames them, destroys their confidence, and causes them to reject their heritage. ${ }^{8}$ Conversely, those in positions of power and influence are free to shape and present the future by controlling the past, a process that systematically denies Native people a dignified history. Adams warns that 'when natives renounce their nationalism and deny their Indianness, it is a sure sign that colonizing schemes of inferiorisation have been successful'. Following from Adams's point, McNickle's fear is that the rejection of the past might be supplanted by indifference to it, particularly amongst the young. However, Archilde offers a possible antidote to this situation through his encounters with discrimination and ubiquitous forms of normative and systemic violence. Through these experiences Archilde is able to move beyond a position of passive disengagement and learn to identify with a hitherto uncertain or indistinct cultural heritage. 


\section{The Surrounded and Cultural Memory}

At the beginning of the novel Archilde is torn between two competing worlds, one of which appears to him as belonging to his mother's past and not his own. Upon his return to the reservation he remarks that 'when you came home to your Indian mother you had to remember that it was a different world', highlighting his sense of cultural disjuncture and the extent to which his mother's 'world' exists independently from his own. ${ }^{9}$ This cultural distancing is symptomatic of what Adams refers to as a rejection of 'Indianness' but which, in this instance, is presented as McNickle's fear of the indifferent Native American youth. Within this context Archilde's initial conflict is more of a passive disengagement than an active rejection or denial-it is simply not important to him at this point in the narrative. For the young, disillusioned Archilde, his mother's Indian heritage loses meaning and becomes a curious, and at times irritating, remainder, or a relic of a fading generation increasingly out of touch with its sons and daughters.

Having been away from home for a year Archilde finds it difficult to even converse with his mother during his first visit to her home. He offers her some money he has earned and attempts to describe his life on the road, but for his mother, Catherine, 'it was all strange' and she 'could not make it into a picture'(2). She sits in silence genuinely confused by his stories of life beyond the reservation, only speaking at last to invite him to a ceremonial feast. Archilde remarks that his mother's feasts were something that he had 'forgotten to include in his visit', a ritualistic event during which you 'gorged yourself on meat until you felt sick, and a lot of old people told tiresome stories' (4). The thought of the feast irritates him but he decides to comply out of good manners, easily dismissing it as a trivial and 'small matter'. Later, while attending the feast, he looks around at the assembled people and recognises how,

In the way he was learning the world, neither Modeste [a venerable and respected elder] nor his mother was important. They were not real people. Buffaloes were not real to him either, yet he could go and look at buffaloes every day if he wished, behind the wire enclosure of the Biological Survey reserve. He knew that buffaloes had been real things to his mother, and to the old people who had come to eat with her tonight. To him they were just fenced up animals that could be shot, though you could take photographs of them. (62)

Archilde's image of the animals 'fenced up' and waiting to be shot or photographed is particularly telling, suggesting that this is also how he perceives his mother's generation who, like the buffalo, await their own annihilation within the confines of the reservation, in effect a biological 'reserve' in its own right. That he could 'go look at buffaloes every day if he wished' reinforces the notion that even to Archilde, the son of a respected elder in the community, the old ways have been shorn of their greater cultural significance. When questioned about his cultural apathy during the feast, he responds initially by distancing himself from his mother's generation, saying 'if I had been born in the old days [...] then I would not be as I am now. You people talk about the old days as if they were here. But they are gone, dead. So don't tell me what I ought to do to be like that' (63). However, as Modeste and 
the other elders continue in 'digging up their troubles and telling stories of the old days' (64), Archilde finds himself being drawn into the heartache of their simple narratives, almost in spite of himself. He notes that even though he had 'not intended to listen' he had 'heard every word', and that the occasion had left 'a spark of gay remembrance in his mind' (66).

Modeste succeeds in striking a chord when he tells Archilde the history of his people. He explains that 'perhaps this talk of fighting and men dying means little to you. It is a little thing now, but when it was happening it seemed big. You will die easily, but if you had lived then you might have died fighting to live' (72). Modeste's intention is both to rebuke Archilde for his unwillingness to be drawn into a larger debate about the fate of the Salish people and to teach him a lesson in what has past and been lost. The notion of 'fighting to live' resonates with Archilde, and he realises that he is in part defined by the ongoing ideological battle for the cultural survival of his people. Archilde remarks inwardly that having listened to the old stories all his life, this was the 'first story about his people that he had understood' (194), and on this occasion he had actually seen it happen for the first time:

First the great numbers and the power, then the falling away, the battles, the starvation in the snow, the new hopes and the slow facing of disappointment, and then no hope at all, just the living in the past. He had heard the story so many times, but he had not listened. It had tired him. Now he saw that it had happened and it left him feeling weak. It destroyed his stiffness toward the old people. He sat and thought about it and the flames shot upward and made light on the circle of black pines. (74)

This event marks the beginning of Archilde's identification with his cultural past and, by extension, his transformation and regeneration. He has invested in and become part of a shared cultural memory that will begin to bind him to a past he had hitherto been unable to fully appreciate. Modeste's description of the great disappointment, the absence of hope and, finally, the admission that his people live only in the past is a deeply troubling one. Archilde 'sees' a reflection of his own predicament and the terrible violence that has been visited upon his ancestors, as well as the ways in which that violence continues to haunt his people, embedded in the very fabric of their inherited cultural memory. In that moment of clarity Archilde sees that he too is part of that shared memory, that he too has been living in a world of 'the conquered'.

Connecting with a meaningful past that can present a challenge to the forces of colonialism is one of the most important objectives of the conquered. Within the context of the novel the Salish people are the conquered, struggling to find their place in a world that no longer makes sense to them. In these instances the act of storytelling becomes a defence mechanism, a defiant act designed to protect what remains of a fragmented past. At stake here is not only Archilde's individual identity but also the identity and cultural history of the Salish people, and so Archilde must either discover this new identity for himself or leave the reservation never to return.

Similarly, Archilde's return prompts a process of difficult introspection for his mother, Catherine, who is deeply troubled by the fact that the lives of her eldest sons Archilde and his outlaw brother Louis seem so drastically at odds 
with her own existence. The awkward silences and the continual misunderstandings that exist between them are indicative of the strained relationship these characters share with their past and present selves and the different worlds they inhabit:

Now in old age she looked upon a chaotic world - so many things dead, so many words for which she knew no meaning; her sons developing into creatures such as had never lived in her childhood (a son might steal horses but a mother was respected); the fires of hell slashing the gloom of a summer evening. [...] she could not understand the ruin that had overtaken her [...] how was it that when one day was like another there should be, at the end of many days, a world of confusion and dread and emptiness? (22)

This disjuncture is perhaps best illustrated early in the novel during a highly symbolic hunting trip in which Archilde agrees to accompany his mother for what threatens to be her last opportunity to participate in the hunting traditions of her people. For Archilde, who is reluctant to go from the outset, the trip presents itself as little more than a 'piece of foolishness', a performance no more remarkable than a walk in the woods (115). For Catherine the trip is a real cultural event, whereas for Archilde it remains an empty expression devoid of any larger cultural associations. However, irrespective of his initial disinterest, this event marks the beginning of a new journey of self-discovery for both characters. As he and his mother press further along the hunting trail he recalls how having listened to Modeste's tale on the night of the feast, he had been started on a 'new train of thought regarding not only his mother but all the old people,' conceding that the stories of the old people 'kept him wondering about their lives' (113).

Despite this growing curiosity Archilde continues to daydream about life beyond the reservation, the 'gleaming lights of the city, any city', admitting to himself 'that this, his home, was a strange country' (120), which demonstrates that even at this critical point in the narrative Archilde continues to see himself as a child torn between two worlds. His cultural disassociation is finally brought to crisis point during the climax of this scene when the local warden shoots Archilde's younger brother Louis, a small-time horse thief who has been hiding in the mountains and who unexpectedly visits the campsite shortly before the arrival of the warden. During a heated exchange about the killing of a doe out of season, the warden mistakenly believes that Louis is about to reach for his rifle and reacts instinctively by shooting him dead. Archilde is stunned:

There was no accounting for what happened next. Archilde saw only the final action, not what led to it. He was near the warden, watching him stoop to examine Louis. Then he saw the officer bend at the knees. His face was twisted with pain. The old lady had hit him in the head with a hatchet. (I27)

In that instant Archilde's otherness is shattered and what was, for him, an unremarkable ramble in the woods becomes a moment of inescapable cultural affirmation. Any chance he might have had to leave the reservation and commence a new life is instantly negated. He reflects on how up until this point the road away from the reservation had 'stood waiting' for him (132), 
only he had allowed the elders to 'talk him into staying' and become part of their tragic history. In killing the warden, Catherine forces Archilde to enter into the crisis of her 'old' Indian world. In the hours that follow Louis's death Archilde assumes control of the situation and speaks on her behalf, becoming her voice, effectively unifying mother and son and the worlds they represent. When Archilde speaks for his mother, he is in effect attempting to move beyond this moment of cultural paralysis and carry her voice forwards, to explain the horrific events of the last few days to his heartbroken father, telling him that they had 'found him yesterday' and 'somebody' had shot him (133-34).

However, there is a further step to be taken here: it is not enough for Archilde simply to be shocked into action; he must also reconnect with the cultural identity of his people in a truly meaningful way if he is to be to the vehicle that can move them out of this crisis and into a new age of prosperity and pride. Archilde has to undertake a wholesale, ideological revolution of mind, body, and soul if he is to successfully free himself from the constraints of systemic violence that subjugate his community. On this point Žižek argues that in a "radical revolution, people not only "realise their old (emancipatory, etc.) dreams"; they have also to reinvent their very modes of dreaming, ${ }^{10}$ which in the case of Archilde represents a return to, and re-envisioning of, the cultural memory of his people. Cultural memory can only become meaningful to Archilde once his relationship to his wider cultural past has been formed through an encounter with 'irrational' violence: that which appears to be a shocking break from the normal running of society-the double murder of Louis and the warden-but which is in fact the violent expression of a deeply ingrained colonial prejudice. ${ }^{11}$ Put simply, Archilde's inherited cultural memory only becomes real through violent encounters with symbols of colonial power and the economic/political systems that maintain them. What outwardly appears to be a stand-alone episode of violence is actually symbolic of an underlying systemic desire to destroy the Indian population. The warden's casual killing of Louis is so devoid of emotion that it can be viewed as the unthinking, automatic reaction born of a deeply engrained systemic prejudice. Equally, Catherine's swift and merciless retribution is not only directed towards the man who has just killed her son, but the systems and structures which compel him to act with such unconscionable indifference. When Archilde emerges from the forest with the body of his brother, accompanied by his now silenced mother, he stands at the tipping point of his new identity, but his transformation is still incomplete and it will require additional violent encounters before this will be realised in its entirety.

One principle character who believes in Archilde's potential to save the future of his people is the widely 'honoured and loved' (135) retired Jesuit priest, father Grepilloux, who has been documenting the spiritual 'progress' of the Salish people and acts as an amateur anthropologist throughout the text. He fervently believes that Archilde represents the last, best hope of his people in that he is, at least at the start of the novel, effectively dislocated from his cultural past and therefore open to suggestion:

This Archilde is the answer we were looking for [...] we were asking ourselves how it had happened that certain bad ones had come among us and spoiled the 
fruit. We could not see how it would end. Our vision was short, as it always is. It was inevitable that a new age would come. It is beginning now. And your boy is standing there where the road divides. He belongs to a new time. He may not stay in this valley, and it makes no difference whether he does or not; it is what he makes of himself that will count. It will be felt by all. (108)

In other words, early in the narrative Archilde represents McNickle's greatest fear: a culturally indifferent Indian, poised at what Fanon and Adams perceive as the potentially devastating endpoint of colonial assimilation. Grepilloux understands the importance of Archilde as a transitional figure within the community, although the ramifications of Archilde's cultural dislocation are unclear to him as an outsider. Significantly, as a Jesuit priest, or 'black robe', he represents one of the very organs of systemic violence that McNickle repeatedly scrutinises in the text. Several months after the death of Louis, Archilde visits the old Jesuit missionary school where generations of Salish children had been taught to reject their 'pagan beliefs' and fear the wrath of God. As he explores the old church, 'images that lay at the beginning of life' begin to awaken within him. With the stories of Modeste and his experiences on the mountain still fresh in his mind, the former 'tyranny' of the church loses its potency (99). Returning now he sees it as an 'empty room', describing the pious fears of his youth as the fear of a 'strange object at night and then going forth by daylight to examine the meaningless bogy' (103-04), an event which sees the 'simple faith of childhood die quietly' within him (105).

For Archilde to counter these forces he has to be motivated to oppose them and return to a point in the collective cultural memory of his people when they stood apart from the forces of colonialism, or even further back, before the arrival of the first colonists in America. In a much quoted line from his 'Theses on the Philosophy of History', Walter Benjamin tells us that 'To articulate the past historically does not mean to recognize it "the way it really was" (Ranke). It means to seize hold of a memory as it flashes up at a moment of danger. ${ }^{12}$ In these flashing moments, recalling the fears and anxieties of his formative years, Archilde experiences an epiphany: he realises that he is an important part of the story of his people. He sees the lies that have been spun to force the young to fear their true ancestry, and recognises the hypocrisy that lies behind life on the reservation. What is past is not as important as what is passed on, and he begins to feel a kinship, cultural awareness, and a growing sense of responsibility for the living memory of his people which he had never expected to experience. David Murray argues that the question of whether Indian identity is frequently 'measured by blood, expressed through kinship and genealogy, or through culture and place' remains to this day a multifaceted problem in Indian writing, reflecting the 'complexity of arguments over Native American's actual legal and cultural status in America. ${ }^{13}$ He goes on to say, however, that in either case it is the "problematic relation to the past and the role of the past in memory, personal and tribal, and in self-definition which continues to be a major theme', highlighting the complex relationship between memory and identity in Native American literature. McNickle takes this argument a step further by presenting a character who struggles, at least at first, to 'see' the past through the eyes of his people. In the event, the significance of Modeste's stories as archives of cultural and collective memory is only revealed once Archilde is forced to a 
point of existential crisis - with the murder of his brother and the warden - and must reflect on the wider, historical context of his Native identity.

The ritualised stories of Modeste and the elders operate here as what Pierre Nora describes as 'sites of memory': cultural and spiritual archives generated to protect modes of identity which would otherwise be forgotten or destroyed. Nora argues that sites of memory such as these testify to a residual compulsion to commemorate or record cultural identity within the secularised and amnesiac modern world. ${ }^{14}$ These stories are the future-proof archives that will in turn give rise to hybridic forms of Native identity, rooted not in a past clouded by colonialism but a symbolic past that seeks to reassert the founding mythologies and cultural identity of native peoples. In the case of Archilde, his cultural transformation is preceded by a violent birth since memory alone is not enough to establish a meaningful connection to the past. For this to happen, the ongoing and largely unseen systemic violence that denigrates the Native community must be exposed before it can be successfully challenged, for while Modeste's stories present conflict in terms of actual wars and violent battles, for Archilde such battles can be only stories. The conflict of his generation is that of trying to oppose the unseen forces which continue to dismantle and disqualify Native identity. It is for this reason that having experienced episodes of irrational violence, Archilde can finally 'see' his place in the ongoing story of his people (74). Modeste tells Archilde that had he lived then, in the days before the great sorrows, he would have died 'fighting to live' since at least then the enemy was easily identifiable, whereas now they have taken the enemy into themselves (72).

When acts of actual physical violence occur within the narrative, they remind the reader that the desire of the Native characters to rebel and fight back, or, at the very least, a desire to react violently to current conditions has always been simmering beneath the surface of the narrative. In The Surrounded we find a community whose people, customs, traditions, and cultural way of life have been subsumed, after generations of persecution, by the normative violence of everyday life, or as Žižek puts it, those 'subtle forms of coercion that sustain relations of domination and exploitation, including the threat of violence.' ${ }^{15}$

Put another way, the everyday violence to which these characters are subjected has existed for such a long time and has been so often defined and then redefined by periods of extreme persecution that it simply exists as part of what Hannah Arendt refers to as the 'unfortunate but acceptable logical and rational consequence of a stubborn, ingrained prejudice. ${ }^{16}$ We surrender our moral objections and human empathy to an automated bureaucratic process, absolving individuals and institutions of responsibility since the outcome serves the 'greater good'. Native Americans have experienced the full range of dehumanising effects of bureaucratic terrorism and legislative violence, from the theft of ancestral lands to the denial of effective legal representation and citizenship. In The Surrounded characters have been subsumed to such an extent that the sustained acts of violence against them have become normalised and unremarkable. Under such conditions it takes episodes of overt physical violence to draw critical attention to that fact. 
Accordingly, the Salish people are presented as non-people. They exist as a cultural community only in as much as they exist as a population legislated for and organised under state and federal law. They exist in the 'twilight zone' of systemic and bureaucratic violence, where the background noise of normative violence has eroded their agency as a community. All they can do is evoke a hybridic past of myth and legend which speaks directly to them and once again makes them centre of their universe, renewing their geographical and spiritual ties to their land, rituals, customs, dances, and language. Through these narratives the Salish are able to reassert themselves as the masters of their destiny, as the subjective agents looking out across the world, not lost within the static of a dominant colonial culture. As such the acts of violence against the characters, their trauma and on-going suffering is rendered ostensibly invisible to others and to a not insignificant degree even to themselves.

Interestingly, much of this violence is delivered under the banner of tolerance and even, somewhat perversely, under that of assistance and help. One of the most interesting characters in this regard is Catherine, a full blood Salish woman raised in the missionary school and trained in domestic skills, who desperately clings to her Catholic beliefs until the end of the novel and her life, when she finally rejects not only her Catholicism but all aspects of what she sees as her former, colonised life. Recalling her experiences of Catholic Mass at the Jesuit mission, Catherine describes how the traditional religious beliefs of the Salish were often denigrated by the priests:

At High Mass one of the Fathers would sometimes turn his sermon upon 'pagan beliefs' and he would get very angry about it. He would say that whoever clung to them would burn in hell forever. When he spoke like that the old lady would pretend she did not hear, because it made her feel sad to be told the past was evil. (174)

Following the death of Louis, Catherine's Catholic faith begins to waver and then fail altogether. As a woman whose devotion to the church had gained her the nickname 'Faithful Catherine', the decline of her Catholic faith and the return of her 'pagan beliefs' is at first shocking and then empathically reassuring.

The Jesuit priests who live in the community believe that they are helping the Salish by saving their souls and assisting them to become more 'civilised', while Catherine's domestic training is seen as a positive gesture which will see her fully prepared for life in the domestic sphere enhancing her abilities as a wife and mother. Upon graduating she is given a set of cooking pots, a stove, and other household items, all of which she immediately abandons to rust. She admits that while the Sisters 'had taught her many arts' they had not 'taught her to be interested in using them' (171). Her rejection and quiet rebellion tells us that even under the watchful eye of colonialism Catherine has remained true to her Indian identity, at least on an unconscious level, for the entire span of her life. In discarding the pots and pans, overt symbols of a domestic life underpinned with powerful ideological connotations, she is defiantly attempting to break away from a prescribed path designed to 'liberate' Indians from themselves and assimilate them into mainstream American society. 
Just as Catherine has been able to overcome forces of cultural assimilation and has remained firmly rooted in her Indian heritage, Archilde is able to move between the two worlds of a symbolic past and an optimistic future. Despite her strong Indian identity and spiritual connection, Catherine's Catholicism is the one idiosyncratic remainder of which she struggles to rid herself until the last hours of her life when, despite the pleading of the attendant priest, she refuses the sacrament. As she lies dying, the other Salish women, thinking that she is already dead, have given themselves over to mourning and sit around wailing. At this point, Archilde, who has been away in town, returns to find his mother in critical condition. Miraculously the old woman, sensing her son is near, once again opens her eyes and whispers the words 'no priest' to Archilde, who is stunned and confused by her emphatic last request. He stands for a moment and ponders, thinking that perhaps she was merely delirious, since 'everybody knew how faithful his mother had been' and 'surely she would not change at this last hour (259)'. As the scene closes and Archilde's mother lapses into unconsciousness the narrator remarks that it was a 'mysterious thing, this dying and coming to life! There must be a special power in that Archilde' (260). This indicates that Catherine's final act is one of rebellion: her rebirth as an Indian, unencumbered by the remnants of her colonial past, is an act which also reestablishes the maternal link between an Indian mother and her formerly disaffected Indian son.

\section{Conclusion}

Current thinking on the subject of systemic violence is well suited to close readings of texts that examine the experiences of Native Americans. In McNickle's novel, it becomes manifest through acts of violence: the brutal forms of physical violence perpetrated on or by various characters, as well as Catherine's violent stand against cultural assimilation. As a consequence, we see the creation of the young, transitional character, Archilde, who is able to reconnect to a rarefied past through acts of ritualised remembering, such as the carefully crafted stories repeatedly told by the community elders. The 'invisible' forces of systemic violence that haunt every aspect of life on the reservation and its population operate like an automated, self-contained ideology machine, insidiously imposing colonial expectations upon the native inhabitants. 'Irrational' acts of violence within the text provide Archilde with glimpses of an obscure past while reasserting a renewed relationship with his estranged mother, who rejects her cultural assimilation and reclaims her Indian identity. In the event, both characters engage with a previously clouded sense of belonging and cultural identity, with Archilde representing the last hope of his generation since he is able to move between different cultural worlds and in so doing carry the cultural memory of his people forward.

Within this nexus of violence, the conflict between the old way of life and the pressures of the modern world is often played out through the process of storytelling and ritualistic remembering. Consequently, McNickle's novel reveals how storytellers can attempt to counter the forces of systemic violence by appealing directly to the imagination of the reader and allowing them to 'see' 
beyond its limitations. However, in concluding his novel McNickle denies Archilde and the reader a satisfying ending. Having fled from the Sheriff and the possibility of a jail term with his girlfriend Elise and young nephews, Archilde takes refuge in the surrounding forest hoping to leave the reservation behind and start afresh with his new family. When the sheriff finally catches up with the renegade group he is uncharacteristically cordial, and in a scene oddly reminiscent of the earlier hunting trip, Elise stuns the sheriff by hurling hot coffee in his face before shooting him dead. Moments later the Indian Agent arrives in the clearing having witnessed the whole scene. Archilde realises that it had been the presence of these unseen men that had tempered the sheriff's behaviour and any hope of freedom had dissolved in the moment that Elise pulled the trigger. The final scene, then, is a depressingly fatalistic one, with the Agent remarking 'don't you people ever learn that you can't run away' (297) and Archilde resigning to hold out his hands to be handcuffed. Despite his development and growing sense of identity Archilde's life appears destined to run an ultimately catastrophic course. McNickle's last word is an admission that the power of systemic violence and the prejudice it engenders is far greater than that of any individual and that the Indian story must remain, at least for the time being, a tragedy.

\section{University of Warwick}

\section{Notes}

1. Frederick E. Hoxie, 'Exploring a Cultural Borderland: Native American Journeys of Discovery in the Early Twentieth Century', in American Nations: Encounters in Indian Country, 1850 to the Present, ed. by Frederick E. Hoxie, Peter C. Mancall, and James H. Merrell (New York: Routledge, 2001), pp. 265-87 (p. 265)

2. Slavoj Žižek, Violence (London: Profile Books, 2008), p. 1.

3. Louis Owens, Other Destinies: Understanding the American Indian Novel (Norman: University of Oklahoma Press, 1992), p. 61.

4. Joy Porter, 'Historical and Cultural Contexts', in The Cambridge Companion to Native American Literature, ed. by Porter and Kenneth M. Roemer (Cambridge: Cambridge University Press, 2005), pp. 39-68 (p. 55).

5. Owens, pp. 49-55.

6. Owens, p. 22.

7. Dorothy R. Parker, Singing an Indian Song: A Biography of D'Arcy McNickle (Lincoln: University of Nebraska Press, 1992), p. 59.

8. Howard Adams, cited in Jace Weaver, That the People Might Live: Native American Literatures and Native American Community (New York: Oxford University Press, 1997), p. 19.

9. Lucy Maddox, Citizen Indians: Native American Intellectuals, Race \& Reform (Ithaca, NY: Cornell University Press, 2005), p. 169.

10. Slavoj Žižek, Living in the End Times (London: Verso, 2010), p. 78.

11. Žižek, Violence, p. 2.

12. Benjamin, Walter, 'Theses on the Philosophy of History', in Illuminations, ed. by Hannah Arendt, trans. by Harry Zohn (London: Jonathan Cape, 1970), pp. 253-64 (p. 255).

13. David Murray, Forked Tongues: Speech, Writing and Representation in North American Indian Texts (Bloomington: Indiana University Press, 1991), p. 81. 
14. Pierre Nora, 'Between Memory and History: les Lieux de Memorie', trans. by Marc Roudebush, Representations, 1 (1989), 7-24 (p. 12).

15. Žižek, Violence, p. 8.

16. Hannah Arendt, On Violence (London: Harvest Books, 1970), p. 76.

\section{Works Cited}

Arendt, Hannah, On Violence (London: Harvest Books, 1970)

Benjamin, Walter, 'Theses on the Philosophy of History', in Illuminations, ed. by Hannah Arendt, trans. by Harry Zohn (London: Jonathan Cape, 1970), pp. 253-64

Dawes, Henry, The Dawes Act, 8 (February 1887), <http://www.pbs.org/weta/thewest/resources/archives/eight/dawes.htm > [accessed 4 October 2010] (paragraph 2 of 9)

Hoxie, Frederick E., 'Exploring a Cultural Borderland: Native American Journeys of Discovery in the Early Twentieth Century', in American Nations: Encounters in Indian Country, 1850 to the Present, ed. by Frederick E. Hoxie, Peter C. Mancall, and James H. Merrell (New York: Routledge, 2001), pp. 265-87

Maddox, Lucy, Citizen Indians: Native American Intellectuals, Race \& Reform (Ithaca, NY: Cornell University Press, 2005).

McNickle, D’Arcy, The Surrounded (Albuquerque: University of New Mexico Press, 1997)

-_- Native American Tribalism: Indian Survivals and Renewals (Oxford: Oxford University Press, 1993)

- - - Wind from an Enemy Sky (Albuquerque: University of New Mexico Press, 2003)

Murray, David, Forked Tongues: Speech, Writing and Representation in North American Indian Texts (Bloomington: Indiana University Press, 1991)

Nora, Pierre, 'Between Memory and History: les Lieux de Memorie', trans. by Marc Roudebush, Representations, 1 (1989), pp. 7-24

Owens, Louis, Other Destinies: Understanding the American Indian Novel (Norman: University of Oklahoma Press, 1992)

Parker, Dorothy R., Singing an Indian Song: A Biography of D'Arcy McNickle (Lincoln: University of Nebraska Press, 1992)

Porter, Joy, 'Historical and Cultural Contexts', in The Cambridge Companion to Native American Literature, ed. by Porter and Kenneth M. Roemer (Cambridge: Cambridge University Press, 2005), pp. 39-68

Weaver, Jace, Native American Literatures and Native American Community (New York: Oxford University Press, 1997)

Žižek, Slavoj, Living in the End Times (London: Verso, 2010)

-_- Violence (London: Profile Books Ltd, 2008) 